\title{
Development of mathematical learning instruments based on ethnomathematics in character education learning
}

\author{
Ririn Dwi Agustin ${ }^{1}$, Mika Ambarawati ${ }^{2}$, Era Dewi Kartika ${ }^{3}$ \\ ${ }^{1,2,3}$ IKIP Budi Utomo, Jl. Simpang Arjuno No.14B Kauman Kec. Klojen Kota Malang, Indonesia
}

\begin{tabular}{l}
\hline A R T I C L E I N F O \\
Original Article \\
doi: $10.18860 /$ ijtlm.v1i1.5353 \\
\hline Keywords: \\
$\begin{array}{l}\text { Development, } \quad \text { Learning } \\
\text { instruments, Ethnomatematics, } \\
\text { Character Education }\end{array}$
\end{tabular}

A B S T R A C T

The purpose of this research is to develope mathematical learning instrument based on ethnomatematics in strengthening students' character education. The learning instruments consist of syllabus, lesson plan, and student worksheet. This research is a development study. This research was conducted in grade 8 of junior high school at Indonesia. This research was implemented in three stages, namely: define, design, and develop. The define phase includes the analysis of syllabus, syllabus, lesson plan, and student worksheet; the design stage includes the preparation of learning instruments draft and research instruments; the development stage includes the test of learning instruments, evaluation and perfection of learning instruments. The validation results of expert validators were as follows: syllabus device with a value of 4.62 with a very valid category, student worksheet instruments with a value of 4.59 with a very valid category, while the materials learning device with a value of 3.55 with a very valid category.

(c) 2018 IJTLM. All rights reserved.

*Corresponding author.

E-mail: ririndwiagustin85@gmail.com

How to cite: Agustin, R. D., Ambarawati, M., \& Kartika, E. D. (2018). Development of mathematical learning instruments based on ethnomathematics in character education learning. International Journal of Teaching and Learning Mathematics, 1(1), 24-30.

\section{INTRODUCTION}

The modernization of our national life can not be denied (Danner \& Zambam, 2016; Flora \& Alber, 2017). This has an impact on the decline of our nation's noble cultural values. This is because of the lack of application and understanding of the importance of cultural values in society.

In learning mathematics, ideally students are accustomed to gain understanding through experience and knowledge developed by students in accordance with the development of thinking. Because students have different potential in the functioning of their thinking ability. This is in line with the learning objectives formulated by the National Council of Teachers of Mathematics that students must learn mathematics through understanding and actively building new knowledge from previously possessed experiences and knowledge (Agustin \& Patricia, 2018).

According to Presmeg, there are several critical questions that arise about what ethnomathematics actually is (Brandt \& Chernoff, 2015). So it makes sense that formal academic Eurocentric mathematics must also be regarded as ethnomathematics because it also comes from cultural practices. However, if this is true, then does the ethnomathematics lose its value and purpose. The best way to understand ethnomatematics is to share a few examples. 
Like music, which basically is the arrangement of various tones from time to time (both can be analyzed through a mathematical lens). Music is one of the main examples of ethnomatematics because every culture has their own understanding of what music is and how it works. An ethnomatemist can analyze various patterns, rhythms, chord progressions, and melodies found in music (Brandt \& Chernoff, 2015). Teachers can encourage parents/guardians to join the class to play instruments or singing songs from their culture. This proves that culture can be used for classroom learning.

We used the full enumeration data from the Indonesian Population Census 2010 and applied the most detailed classification of ethnicity (1340 single ethnicity codes). We found that endogamy (marriage between individuals of the same ethnic group) remains the norm across all provinces in Indonesia. Across provinces, there was a negative and significant association between endogamy rates and ethnic fractionalisation index (Utomo \& Mcdonald, 2014). Cultural values that form the basis of the character of the nation is an important thing instilled in every individual. Each individual can better understand, interpret, and appreciate and realize the importance of cultural values in carrying out every activity of life. The cultivation of cultural values can be done through the family environment, education, and in the community environment (Wahyuni, 2013).

Mathematics from identifiable cultural groups or other names given to the relationship between mathematics and culture can help us in the process of humanizing mathematics. It has the intention of building tasks that are based on the culture of the countries in which Portuguese history is connected and by doing so we intend to connect meaning that is easily connected by school children (D'Ambrosio, 2006). The cultivation of cultural values in education can be cultivated with etnomatematics. Ethnomatematics as a mathematics education that integrates the values of culture in the learning of mathematics need to initiate the real integration of cultural values (D'Ambrosio \& Rosa, 2017; Rosa \& Orey, 2016; Rosa \& Gavarrete, 2017; Sirate, 2015).

Mathematics has been a part of human culture for so long. Starting from prehistoric times, Egyptians, Greeks, Indians, Chinese, Romans, to Europeans today. Human creation in the form of culture manifests in the form of ideas, activities and artifacts. Values in the behavior of human culture show the power of aesthetics and the power of human creation. It shows integration between mathematics and culture in a contextual and realistic form. Mathematics as part of culture which can be applied and used to analyze things that are innovative. Thus, mathematics can be used as a tool for developing a superior culture. In addition, mathematics also help humans efforts to solve problems that arise, consciously or not, humans have used mathematics. Likewise in lifestyle of maintaining its culture, it is possible for the community to use mathematical ideas. Mathematical ideas in the context of cultural activities began to be seen by experts in mathematics education as an important matter (Louie, 2017; Nuh \& Dardiri, 2016; Worthington, \& van Oers, 2016).

The ethnomathematical approach has developed significantly in the past two decades and has spread more widely than before. It has become a more used, routine approach, which is implemented in curricula by researchers and teachers around the world. This development process produces: mathematics teaching materials at a certain level, such as examples and exercises, in addition to the enrichment framework. The ethnomathematical approach became the foundation of numerous curricula in national and local jurisdictions. National accrediting institutions, such as the American actually require programs to train teachers so that they will be able embrace an international approach and demonstrate diversity in the curriculum, the student council, and faculty (Fouze \& Amit, 2018). 
The results of the studies conducted by Eglash (1997) and Orey \& Rosa (2007) show evidences that including cultural aspects in the curriculum will have long-term benefits for mathematics learners; that is; cultural aspects contribute to recognizing mathematics as part of daily life, enhancing the ability to make meaningful connections, and deepening the understanding of mathematics. Damazio (2004) suggests that the pedagogical elements necessary to develop the mathematics curriculum are found in the school community.

The application of ethnomatematics-based character education which is integrated into learning can be through the development of learning instruments. Learning instruments consist of syllabus, materials learning, student worksheet, learning resources, instructional media, and evaluation tool. However, in this study it will be developed learning instrumens that is syllabus, learning program plan, and student.

\section{METHOD}

This study is a research development which was conducted in grade 8 students of SMP Negeri 2 Tarik Sidoarjo, Indonesia. The study was conducted in three stages (define, design, and develop) as shown in Figure 1. The define phase includes syllabus, lesson plan, and student worksheet. It includes drafting of learning instruments and the design stage is the making of instruments. The develop phase includes test of instructional instruments, evaluation as well as refinement of learning instruments. These three stages are an integral part of a development research design.

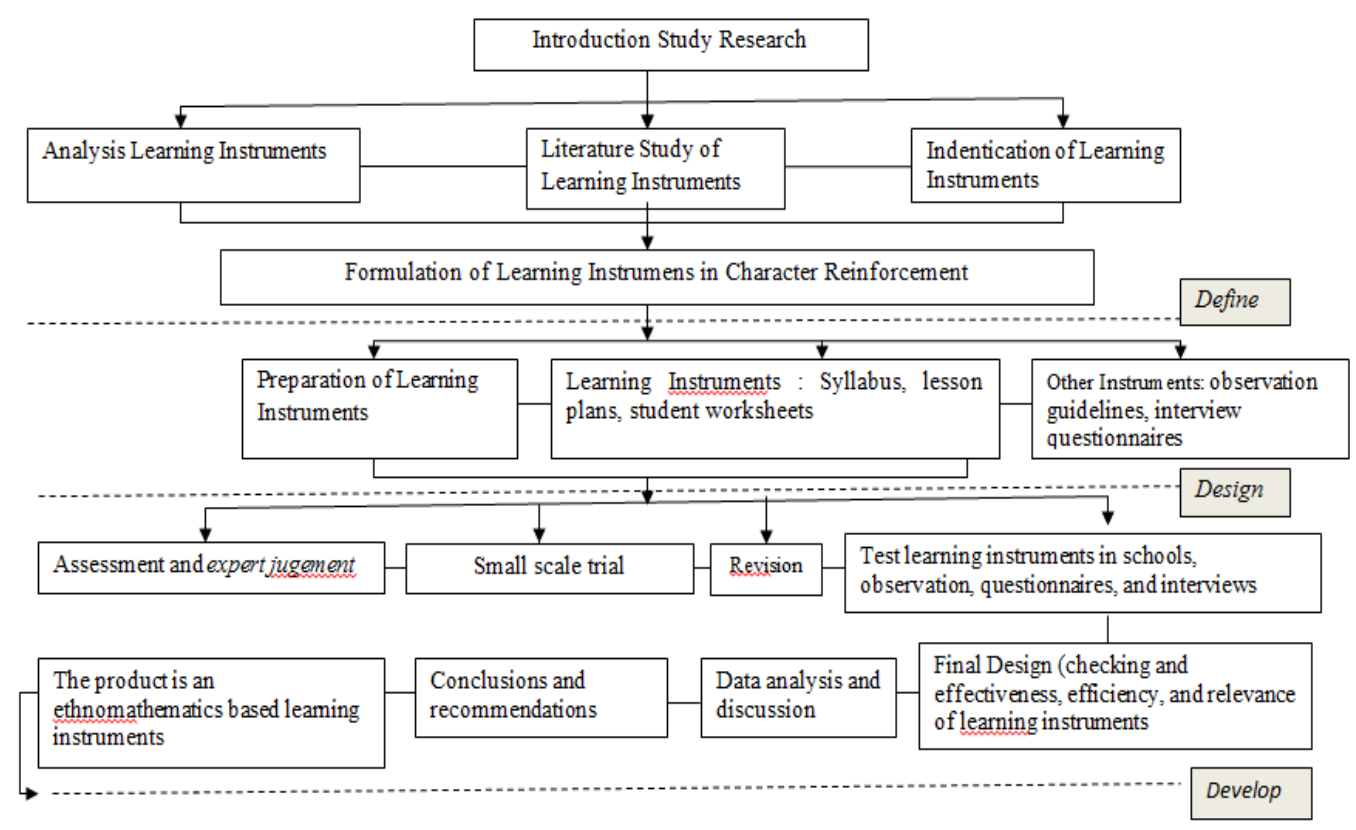

Figure 1. A scheme of the research development

\section{RESULTS AND DISCUSSION}

Research on ethnomatematics continues to be developed. Richardo (2016) conducted a research on the role of ethnomathematics in the application of mathematics learning in the 2013 curriculum. The results showed that the ethnomatematics in mathematics learning gave a new atmosphere that learning mathematics was not only confined inside the classroom but outside the classroom activity by visiting or interacting with local culture could be used as Mathematics 
learning media. Meanwhile, in terms of the learning approach, ethnomatatics is aligned with a mathematical learning approach that is suitable to applied in the 2013 curriculum.

Following the development of the ethnomathematical trend as an educational-cultural field, several proposals were suggested and numerous attempts were made to develop curricula with multicultural mathematicals ideas that include traditional cultural values, traditions, symbols, and mechanisms for the purpose of aiding the instruction of mathematical subjects. This trend testifies to the importance and centrality of ethnomathematics, which appears now not only as a matter of enrichment or the property of a certain society of power, but as a matter that requires an overall effort to develop. Therefore, cultural values must be utilized in mathematical education nd instruction, out of solidarity and respect for all cultures as such, while preserving their future existence (Sirate, 2015).

In this study the learning intstruments made are syllabus, lesson plans and student worksheets. This learning instruments is not only contain pure mathematics material but also insert cultural values. Therefore this device is called etnomatematics because of its cultural value. The examples of etnomathematics in the learning instruments are presented in Figure 2.

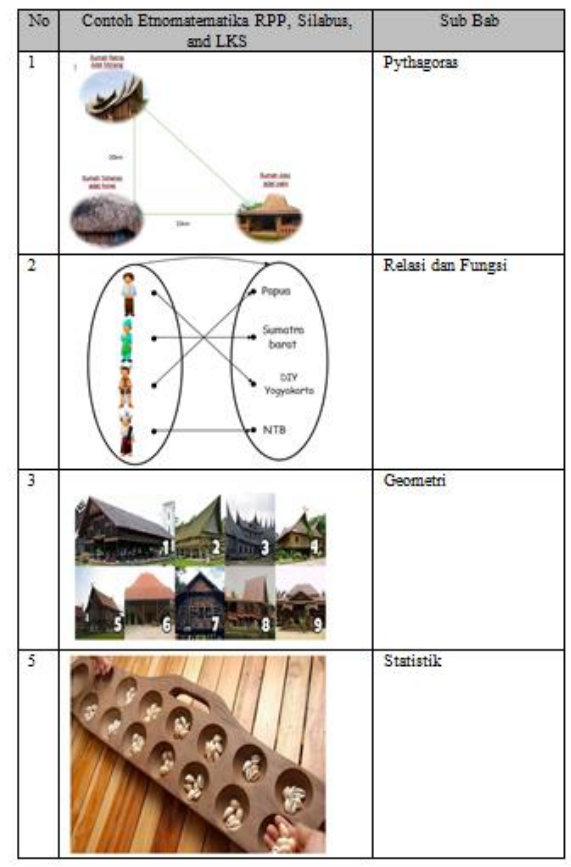

Figure 2. Some examples of ethnomathematics in the learning instruments

Each of these devices is validated by two validators. One is mathematics expert validator and the other is expert validator of mathematics and sociology of culture. The validators assess material, media and language aspects. The assessment result of ethnomatematics devices is presented in Table 1.

Table 1. The assessment result of ethnomatematics devices by validators

\begin{tabular}{cccc}
\hline No. & Device Type & Average & Category \\
\hline 1 & Syllabus & 3.55 & Very Valid \\
2 & Materials Learning & 4.62 & Very Valid \\
3 & Student Worksheet & 4.59 & Very Valid \\
& Conclusion & & Very Valid \\
\hline
\end{tabular}


Learning instruments is valid if it passed the assessment phase by material experts, media experts, and linguists expert. Thus, when the learning instruments passed the assessment phase by media expert, and linguist expert, this learning instruments can be declared eligible/valid to be developed. Validation results from the following expert validators: syllabus device with a value of 4.62 with a very valid category, student worksheet device with a value of 4.59 with a very valid category, while the materials learning with a value of 3.55 with a very valid category.

After going through the validation stage by material experts, media experts, and language experts, the learning instruments were tested by distributing student response questionnaires. Based on the data analysis, the student response questionnaire and obtained results that the developed learning instruments get a very good category with a percentage of $89 \%$. This shows, the learning instruments developed are appropriate to be used as a learning instruments for ethnomatematics.

The effectiveness of mathematics education and its effect on student achievement is high on the agenda of many countries, which is one reason why many researchers have developed and implemented the ethnomathematics curriculum (Adam, 2004; Malaty, 1989; Orey, \& Rosa, 2006; Russell, 2017). This has similarities with my research which in it makes learning devices with the aim of being able to be used in the learning process that refers to the school curriculum. For example, Lipka, Andrew-Ihrke, and Yanez (2011) presented findings from educational projects conducted among American Indians and American-Alaskans for the purpose of examining the influence of local culture on teaching mathematics for these students. The researchers worked with Yup'ik tribal elders to include daily cultural actoivities in the school curriculum. Thus, students initially study in the theory of traditional methods of mathematics education and then apply it in practice. This study produced learning instruments for teaching mathematics with ethnomatematics based on the character of strengthening education which was carried out in schools. Being students know Indonesian culture, besides that, relationships in mathematics learning are shown to strengthen activities in the classroom when teachers teach or even students do student worksheets.

\section{CONCLUSION}

The development of ethnomatematics based mathematics learning instuments in strengthening character education produced mathematical learning instruments (syllabus, materials learning, student whorksheet) which is contain Indonesian cultural values and character education values. This development has been validated by expert validators so which it is decent to public use. In general, this research will be implemented in three stages, namely: define, design, and develop. The define phase includes the analysis of syllabus, materials learning, and student worksheet; the design stage includes the preparation of draft learning instruments and research instruments, the development stage includes the test phase of learning instruments, evaluation and perfection of learning instruments. The validation results of expert validators are as follows: syllabus device with a value of 4.62 with a very valid category, student worksheet instruments with a value of 4.59 with a very valid category, while the materials learning device with a value of 3.55 with a very valid category.

\section{ACKNOWLEDGMENTS}

We would like thank you to IKIP Budi Utomo Malang which support our research. Also, we gratitude to Ministry Research and Technology which gives research fund. 
International Journal on Teaching and Learning Mathematics

2018, Vol. 2, No. 1, pp. 24-30

P-ISSN: 2621-2188, E-ISSN: 2621-2196

\section{REFERENCES}

Adam, S. (2004). Ethnomathematical ideas in the curriculum. Mathematics Education Research Journal, 16(2), 49-68.

Agustin, R. D., \& Patricia, F. A. (2018). Development of materials in materials module with appropriate resolution application. In University of Muhammadiyah Malang's 1st International Conference of Mathematics Education (INCOMED 2017) (pp. 18-20). Atlantis Press.

Amit, M., \& Qouder, F. A. (2017). Weaving culture and mathematics in the classroom: The case of Bedouin ethnomathematics. In Ethnomathematics and its Diverse Approaches for Mathematics Education (pp. 23-50). Springer, Cham.

Brandt, A., \& Chernoff, E. J. (2015). The importance of ethnomathematics in the math class. Ohio Journal of School Mathematics, 1(71), 31-36.

Damazio, A. (2004). Especifidades conceituais da matemática da atividade extrativa do carvão [conceptual specifications of mathematical activities of coal extraction]. Coleção Introdução à Etnomatemática [Introduction to Ethnomathematics Collection] (Natal RN). Brazil: UFRN.

Danner, L. F., \& Zambam, N. J. (2016). Modernization and development in Brazilian Amazon: giving voice to those who have no voice as basis of an alternative political, cultural, and economic project. Clareira-Revista de Filosofia da Região Amazônica, 2(2), 62-84.

D’Ambrosio, U. (2006). Ethnomathematics: Link between traditions and modernity. Rotterdam, Netherlands: Sense Publishers.

D’Ambrosio, U., \& Rosa, M. (2017). Ethnomathematics and its pedagogical action in mathematics education. In Ethnomathematics and its diverse approaches for mathematics education (pp. 285-305). Springer, Cham.

Eglash, R. (1997). When math worlds collide: Intention and invention in ethnomathematics. Science, Technology, \& Human Values, 22(1), 79-97.

Flora, P., \& Alber, J. (2017). Modernization, democratization, and the development of welfare states in Western Europe. In Development of Welfare states in Europe and America (pp. 37-80). Routledge.

Fouze, A. Q., \& Amit, M. (2018). Development of mathematical thinking through Integration of ethnomathematic folklore game in math instruction, 14(2), 617-630. https://doi.org/10.12973/ejmste/80626

Lipka, J., Andrew-Ihrke, D., \& Yanez, E. E. (2011). Yup'ik cosmology to school mathematics: The power of symmetry and proportional measuring. Interchange, 42, 157-183.

Louie, N. L. (2017). The culture of exclusion in mathematics education and its persistence in equity-oriented teaching. Journal for Research in Mathematics Education, 48(5), 488519.

Nuh, Z. M., \& Dardiri. (2016). Etnomatematika dalam sistem pembilangan pada masyarakat melayu Riau. Kutubkhanah: Jurnal Penelitian Sosial Keagamaan, 19(2), 220-238.

Orey, D. C., \& Rosa, M. (2006). Ethnomathematics: Cultural assertions and challenges towards pedagogical action. The journal of Mathematics and Culture, 1(1), 57-78.

Orey, D., \& Rosa, M. (2007). Cultural assertions and challenges towards pedagogical action of an ethnomathematics program. For the Learning of Mathematics, 27(1), 10-16.

Richardo, R. (2016). Peran ethnomatematika dalam penerapan pembelajaran matematika, 7(2), $118-125$. 
Rosa, M., \& Orey, D. C. (2016). State of the art in Ethnomathematics. In Current and future perspectives of ethnomathematics as a program (pp. 11-37). Springer, Cham.

Rosa, M., \& Gavarrete, M. E. (2017). An Ethnomathematics overview: An introduction. In Ethnomathematics and its Diverse Approaches for Mathematics Education (pp. 3-19). Springer, Cham.

Russell, G. (2017). Indigenous students in relation to mathematics and ethnomathematics. In Transreform Radical Humanism (pp. 191-199). Sense Publishers, Rotterdam.

Sirate, S. F. S. (2015). Menggagas integrasi multikultur pembelajaran matematika: Suatu telaah etnomatematika. Jurnal Pendidikan Dasar Islam, 2(2), 246-263.

Utomo, A., \& Mcdonald, P. (2014). Development, social change and assortative mating: Ethnic marriage pairing in Indonesia. Paper was presented at the Chaire Quetelet (pp.1-29). Louvain-la-Neuve, Belgium: Catholic University of Louvain.

Wahyuni, A., Tias, A. A. W., \& Sani, B. (2013). Peran etnomatematika dalam membangun karakter bangsa. In Prosiding Seminar Nasional Matematika dan Pendidikan Matematika FMIPA Universitas Negeri Yogyakarta (pp.113-118).

Worthington, M., \& van Oers, B. (2016). Pretend play and the cultural foundations of mathematics. European Early Childhood Education Research Journal, 24(1), 51-66. 